\title{
Androgens and androgen-binding protein in the rat epididymis
}

\author{
K. Purvis and V. Hansson \\ Institute of Pathology, Rikshospitalet, Oslo, Norway
}

\begin{abstract}
Summary. The levels of testosterone, dihydrotestosterone (DHT), $5 \alpha$-androstan$3 \alpha, 17 \beta$-diol and androgen-binding protein (ABP) were measured in various segments of the epididymis from adult rats which had been unilaterally orchidectomized for 4 weeks. On the 'intact' side, ABP concentrations were highest in the caput region. The segmental distribution of DHT closely followed that of ABP with the highest concentration in the caput ( $40 \mathrm{ng} / \mathrm{g}$ tissue) and lowest in the cauda ( $10 \mathrm{ng} / \mathrm{g}$ tissue) epididymidis. There was a high degree of correlation $(r=0.98)$ between the concentration of DHT in the epididymis and ABP levels. 'Castration' completely abolished the DHT gradient. The levels of testosterone and androstanediol were lower than those of DHT; most was present in the corpus epididymidis. The relative differences were reduced after 'castration'. It is concluded that ABP in the rat epididymis is the primary factor for determining the concentration of DHT in the epididymal fluid.
\end{abstract}

\section{Introduction}

Testicular androgen-binding protein (ABP) is produced in the Sertoli cell and secreted into the testicular fluid whence it is transported through the efferent ducts and into the epididymis where it is concentrated in the caput (Hansson, Ritzén, French \& Nayfeh, 1975). The purpose of the present study was to examine the influence of ABP in the lumen of the rat epididymis on the concentrations of androgens, which have been reported to be high in this organ (Aafjes \& Vreeburg, 1972; Pujol, Bayard, Louvet \& Boulard, 1976).

\section{Materials and Methods}

Eight adult Sprague-Dawley rats, weighing approximately $400 \mathrm{~g}$, were unilaterally orchidectomized 4 weeks before autopsy to ensure that ABP was not present in the epididymis on that side (French \& Ritzén, 1973).

\section{Homogenization of tissue and preparation of cytosol fraction}

The epididymides from each animal were divided into 5 segments as illustrated in Text-fig. 1 and corresponding segments from each of the animals were pooled, weighed and homogenized in 9 volumes of buffer ( $50 \mathrm{~mm}$-Tris- $\mathrm{HCl}, \mathrm{pH} 7 \cdot 4$, containing $0.25 \mathrm{M}$-sucrose and $1 \mathrm{~mm}$-EDTA). An aliquot $(1 \mathrm{ml})$ of homogenate from each of the individual segments was centrifuged at $105000 \mathrm{~g}$ for $60 \mathrm{~min}$ to isolate the cytosol fraction. The rest of the homogenate was used for androgen determinations.

\section{Assay for androgens}

The epididymal homogenates were subjected to the same purification and chromatographic procedures as have been previously described for rat testis homogenates (Purvis, Calandra, Haug \& Hansson, 1977), with few modifications, and the quantities of steroid in the appropriate chromatographic fractions were measured by radioimmunoassay. Briefly, after the addition of tritiated testosterone, dihydrotestosterone and $5 \alpha$-androstan-3 $\alpha, 17 \beta$-diol (approximately $1500 \mathrm{ct} / \mathrm{min}$ ), the 
homogenates of the pooled epididymal segments (between 8 and $15 \mathrm{ml}$ ) were extracted in duplicate with 3 volumes diethyl ether ( 3 times) by using separating funnels $(50-100 \mathrm{ml})$. After pooling and evaporation of the organic extracts, the residue was dissolved in $1 \mathrm{ml}$ methanol-water $(90: 10 \mathrm{v} / \mathrm{v})$ which was then gently extracted twice with $2 \mathrm{ml} n$-hexane. On each occasion the hexane layer was discarded. The methanol phase was adjusted to $50 \%$ by the addition of water and the result was extracted with methylene dichloride $(5 \mathrm{ml}$, twice). The pooled methylene dichloride extract was then evaporated and the residue dissolved in isooctane $(1 \mathrm{ml})$. The extract was then chromatographed on celite microcolumns to isolate testosterone, dihydrotestosterone and androstanediol. By means of a cross-column arrangement, testosterone and androstanediol were isolated with a celite:ethylene glycol $(2: 1 \mathrm{w} / \mathrm{v})$ stationary phase whilst dihydrotestosterone was obtained with a celite:propylene glycol (1:1 w/v) column (Purvis et al., 1977). Details of the preparation of the chromatographic extract and the subsequent radioimmunoassay, including information on the antibody specificity, are given by Purvis, Brenner, Landgren, Cekan \& Diczfalusy (1975) and Purvis et al. (1977). The recoveries of internal standards $(n=20)$ were $71 \cdot 3 \pm 8 \cdot 8 \%$ (s.d.), $51 \cdot 4 \pm 5 \cdot 7 \%$ and $62 \cdot 0 \pm 8 \cdot 7 \%$ for testosterone, androstanediol and dihydrotestosterone, respectively. The corresponding intra-assay variation (as assessed from the coefficients of variation of duplicate measurements $(n=20)$ ) and interassay variation (calculated as the coefficient of variation of measurements on three aliquots of the same epididymal pool on 3 separate occasions) values were $12.2 \%$ (mean $1.4 \mathrm{ng}$ ), $9.8 \%$ (mean $9.7 \mathrm{ng}$ ) and $9.5 \%$ (mean $15.9 \mathrm{ng}$ ), and $15.1 \%$ (mean $2.1 \mathrm{ng}$ ), $13.4 \%$ (mean $8.5 \mathrm{ng}$ ) and $14.6 \%$ (mean 18.4 $\mathrm{ng}$ ) respectively. Water blanks were at all times negligible. Assays carried out on increasing dilutions of pooled epididymal homogenate derived from three separate regions (corresponding to Segments I + II, III and IV + V in Text-fig. 1) of 8 epididymides gave satisfactory results in every case, except one, when tests of parallelism and linearity were applied to the data (Table 1; Purvis et al., 1977). The exception was for testosterone measurements in Segment III; the deviation from parallelism with standards attained borderline significance $(P<0.05)$. For this reason, testosterone measurements in this segment can only be considered as approximate estimates of the true levels.

Table 1. The data to show parallelism between increasing amounts of endogenous hormone (range in parentheses) in pools of rat epididymal homogenates (8/pool) and standard hormone (see Brenner, Guerro, Cekan \& Diczfalusy, 1973, for details of methods)

\begin{tabular}{|c|c|c|c|c|c|c|}
\hline \multirow{2}{*}{$\begin{array}{c}\text { Epididymal } \\
\text { segment }\end{array}$} & \multicolumn{2}{|c|}{ Testosterone } & \multicolumn{2}{|c|}{ DHT } & \multicolumn{2}{|c|}{ Androstanediol } \\
\hline & $F_{11 n}$ & $F_{\text {par }}$ & $F_{11 n}$ & $F_{\text {par }}$ & $F_{1 i n}$ & $F_{\text {par }}$ \\
\hline Caput & 0.33 & $\begin{array}{c}0.61 \\
(12.5-50 \mathrm{pg})\end{array}$ & 0.48 & $\begin{array}{c}1.55 \\
(50-200 \mathrm{pg})\end{array}$ & $2 \cdot 32$ & $\begin{array}{c}0 \cdot 10 \\
(25-100 \mathrm{pg})\end{array}$ \\
\hline Corpus & 2.09 & $\begin{array}{c}5.02 \\
(12 \cdot 5-50 \mathrm{pg})\end{array}$ & 0.33 & $\begin{array}{c}1.48 \\
(25-100 \mathrm{pg})\end{array}$ & 0.67 & $\begin{array}{c}0.69 \\
(25-100 \mathrm{pg})\end{array}$ \\
\hline Cauda & $0 \cdot 14$ & $\begin{array}{c}0.78 \\
(25-100 \mathrm{pg})\end{array}$ & $1 \cdot 57$ & $\begin{array}{c}2 \cdot 86 \\
(25-100 \mathrm{pg})\end{array}$ & $0 \cdot 80$ & $\begin{array}{c}0.90 \\
(25-100 \mathrm{pg})\end{array}$ \\
\hline
\end{tabular}

$F_{1 \mathrm{la}}=F$ value for linearity $; F_{p a r}=F$ value for parallelism. Tabulated $F_{0.95}(1,12)=4 \cdot 75$.

\section{Assay for $A B P$}

ABP in the cytosol fractions from the various segments of the epididymis was analysed by steadystate gel electrophoresis (SS-PAGE) as described previously (Ritzén, French, Weddington, Nayfeh \& Hansson, 1974). The cytosol fractions were diluted 1:1 (v/v) with the homogenization buffer, giving an overall dilution of $1: 20(\mathrm{w} / \mathrm{v})$. Diluted cytosol $(200 \mu \mathrm{l})$ was layered on the top of polyacrylamide gels prepared as described by Davis (1964). The stacking gel contained $15 \mathrm{nM}-\left[{ }^{3} \mathrm{H}\right]$ dihydrotestosterone (sp. act. $91 \mathrm{Ci} / \mathrm{mmol}$ ), and $2 \mathrm{~nm}-\left[{ }^{3} \mathrm{H}\right]$ dihydrotestosterone were included in the separating gel. After electrophoresis the gels were sliced and the radioactivity from each slice eluted as described elsewhere (Ritzén et al., 1974). 


\section{Other analytical methods}

Protein was determined by the method of Lowry, Rosebrough, Farr \& Randall (1951).

\section{Results}

As shown in Text-fig. 1 and in confirmation of previous studies (Hansson et al., 1975), the highest concentration of ABP in the rat epididymis was found in the caput region. Concentrations then decreased towards the cauda, probably due to resorption from the epididymal lumen. Removal of the testis resulted in the practically complete disappearance of ABP from the whole epididymis after 4 weeks, an effect consistent with its testicular origin (French \& Ritzén, 1973). The segmental distribution of dihydrotestosterone in the normal epididymis closely followed that of ABP, being greatest in Segment I (Table 1). As shown in Text-fig. 2, there is a very high correlation between the levels of ABP and the concentration of dihydrotestosterone in the different segments of the 'intact' epididymis. When the secretion of ABP into the epididymal fluid was prevented by orchidectomy, the concentration gradient of dihydrotestosterone from Segments I to V was completely abolished.

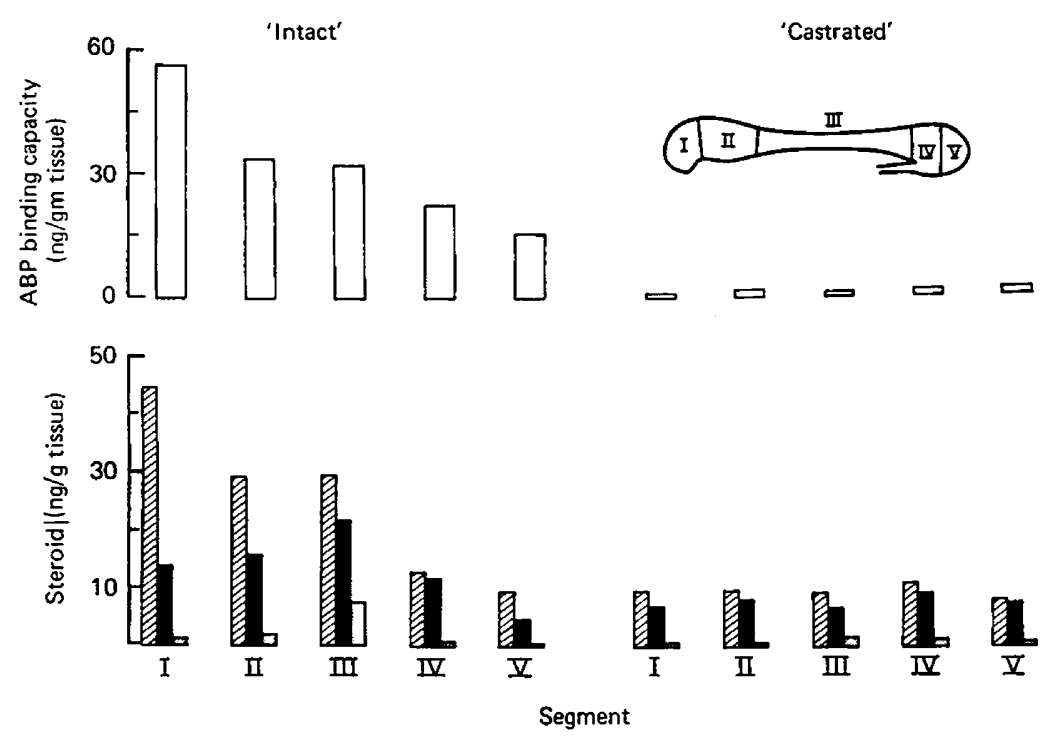

Text-fig. 1. Distribution of androgen-binding protein (ABP), testosterone (stippled columns), dihydrotestosterone (hatched columns) and $5 \alpha$-androstan- $3 \alpha, 17 \beta$-diol (black columns) in pooled segments $(n=8)$ of 'intact' and 'castrated' epididymides from adult rats. The epididymides were segmented as indicated.

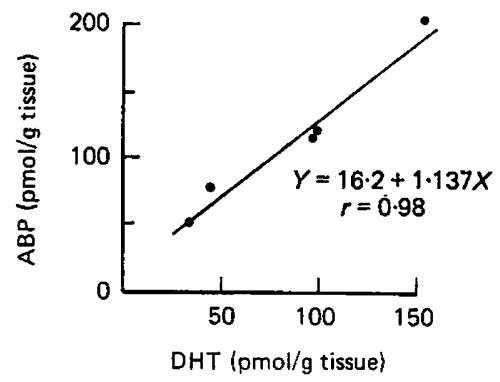

Text-fig. 2. Relationship between molar concentrations of androgen-binding protein (ABP) and dihydrotestosterone (DHT) in pooled segments of rat epididymides. Downloaded from Bioscientifica.com at 04/26/2023 07:41:57AM 
The segmental distribution of testosterone and androstanediol differed from that of dihydrotestosterone and did not appear to be influenced, at least to the same extent, by the local concentrations of $\mathrm{ABP}$.

\section{Discussion}

High concentrations of dihydrotestosterone have been reported in the caput epididymidis by others (Aafjes \& Vreeburg, 1972; Pujol et al., 1976) but an explanation has not been provided. ABP exhibits the highest affinity for dihydrotestosterone of all the androgens tested (Hansson, Djöseland, Reusch, Attramadal \& Torgersen, 1973). Moreover, the binding capacity of this protein (assuming $1 \mathrm{~mol} \mathrm{ABP}$ binds $1 \mathrm{~mol}$ dihydrotestosterone) in the different epididymal segments is comparable to the levels of dihydrotestosterone found in the same segments. Our present results therefore suggest that the presence of ABP in the lumen of the caput epididymidis is responsible for the large accumulation of dihydrotestosterone found in that segment.

The origin of these large quantities of dihydrotestosterone is unclear; some may be derived from the testis and some formed by the epididymal tissue itself. Rabbit efferent duct fluid contains large quantities of dihydrotestosterone which are highly correlated with the levels of ABP in the same fluid (Guerrero, Ritzén, Purvis, Hansson \& French, 1975), and in this species at least, ABP may bind and transport dihydrotestosterone to the caput epididymidis from the seminiferous tubule. However, in the rat, dihydrotestosterone levels in the efferent duct fluid are relatively low compared to those of other androgens (Ritzén et al., 1977): the ratio of testosterone:dihydrotestosterone levels in rat efferent duct fluid $(7: 1)$ is reversed $(1: 23)$ in the caput epididymidis. Quantitatively more important therefore is the formation of dihydrotestosterone by the epididymal tissue itself. The epididymis has been shown to have a great ability to convert testosterone to dihydrotestosterone in vivo (Tindall, French \& Nayfeh, 1972) and in vitro (Gloyna \& Wilson, 1969). Moreover, the finding that systemic injection of testosterone can maintain epididymal dihydrotestosterone levels for a short time after castration (Aafjes \& Vreeburg, 1972) also suggests that the dihydrotestosterone present in the epididymis results, to a great extent, from local metabolism of circulating testosterone. The quantities of ABP remaining in the epididymis at $24 \mathrm{~h}$ after castration would still be sufficient to influence local dihydrotestosterone levels.

$\mathrm{ABP}$ is exclusively localized to the epididymal lumen and there is now strong evidence that the greatest quantities of androgen are also present in the epididymal lumen. Autoradiographs of epididymides from 35 -day-old intact male rats which have received an injection of $\left[{ }^{3} \mathrm{H}\right]$ testosterone show intense concentration of radioactivity in the lumen and little in the epithelial lining (Stumpf \& Sar, cited by Hansson et al., 1975). Furthermore, washing of minced epididymides to remove the luminal contents results in a lowering of the dihydrotestosterone levels in the caput segment (Pujol et al., 1976) to values which are comparable to those found in the 'castrated' epididymis in the present study. The concentrations of testosterone and androstanediol were much lower than those of dihydrotestosterone in all the epididymal segments but there was an apparent accumulation in the corpus region (Segment III). This cannot be explained but might be due to a greater content of plasma steroid, or to segmental differences in androgen metabolism.

Our studies clearly show that ABP is the primary reason for the high concentrations of dihydrotestosterone observed in the rat epididymis. It is generally assumed that only free steroid is available for the target celis. This may be correct for androgens circulating in plasma, but the flow dynamics in circulating blood and in the epididymal lumen are probably not comparable. If the flow of fluid is slow enough and the half-life of dissociation of the DHT-ABP complexes is high enough, the surrounding cells may be able to use the total androgen present. The possibility that ABP may be specifically 'recognized' and 'attracted' by special cells could further give rise to specific localization of the androgenic stimulus. The fact that the morphological integrity of the proximal segments of the epididymis of castrated rabbits cannot be maintained even by supraphysiological doses of androgens (L. Nicander, personal communication) also indicates a role for ABP-bound dihydrotestosterone in the epididymis. 
This work was supported by grants from World Health Organization, Nordic Insulin Foundation and the Norwegian Research Council for Science and the Humanities. We thank M. Purvis and T. Varaas for skilled technical help.

\section{References}

AAFJeS, J.H. \& VREeBURG, J.H.M. (1972) Distribution of $5 \alpha$-dihydrotestosterone in the epididymis of bull and boar, and its concentration in rat epididymis after ligation of efferent testicular ducts, castration and unilateral gonadectomy. $J$. Endocr. 53, 85-93.

Brenner, P.F., Guerrero, R., Cekan, Z. \& Diczfalusy, E. (1973) Radioimmunoassay method for six steroids in human plasma. Steroids 22, 775-794.

Davis, B.J. (1964) Disc electrophoresis. II. Method and application to human serum proteins. Ann. N.Y. Acad. Sci. 121, $404-427$.

French, F.S. \& RITZÉN, E.M. (1973) A high affinity androgen binding protein (ABP) in rat testis: evidence for secretion into efferent duct fluid and absorption by epididymis. Endocrinology 95, 88-93.

GloynA, R.E. \& Wilson, J.D. (1969) A comparative study of the conversion of testosterone to $17 \beta$ hydroxy- $5 \alpha$-androstan-3-one (dihydrotestosterone) by prostate and epididymis. J. clin. Endocr. Metab. 29, 970-977.

Guerrero, R., Ritzén, E.M., Purvis, K., Hansson, V. \& FRENCH, F.S. (1975) Concentration of steroid hormones and androgen binding protein (ABP) in rabbit efferent duct fluid. In Hormonal Regulation of Spermatogenesis, pp. 213-221. Eds F. S. French, V. Hansson, E. M. Ritzén \& S. N. Nayfeh. Plenum Press, New York.

Hansson, V., Duöseland, O., Reusch, E., Attramadal, A. \& Torgersen, O. (1973) An androgen binding protein in the testis cytosol fraction of adult rats. Comparison with the androgen binding protein in the epididymis. Steroids 21, 457-474.

Hansson, V., Ritzén, E.M., French, F.S. \& Nayfeh, S.N. (1975) Androgen transport and receptor mechanisms in testis and epididymis. In Handbook of
Physiology, Endocrinology V, pp. 173-200. Eds R. O. Greep \& D. W. Hamilton. American Physiological Society, Washington.

Lowry, O.H., Rosebrough, N.J., FARR, A.L. \& RaNDALl, R.J. (1951) Protein measurement with the Folin phenol reagent. J. biol. Chem. 193, 265-275.

Pujol, A., Bayard, F., Louvet, J.-P. \& Boulard, C. (1976) Testosterone and dihydrotestosterone concentrations in plasma, epididymal tissues, and seminal fluid of adult rats. Endocrinology 98, 111-113.

Purvis, K., Brenner, P.F., Landgren, B.-M., Cekan, Z. \& DiczfalusY, E. (1975) Indices of gonadal function in the human male. I. Plasma levels of unconjugated steroids and gonadotrophins under normal and pathological conditions. Clin. Endocr. 4, 237-246.

Purvis, K., Calandra, R., Haug, E. \& Hansson, V. (1977) $5 \alpha$ Reduced androgens and testicular function in the immature rat. Effects of $5 \alpha$-androstan$17 \beta$-ol-3-one (DHT) propionate and $5 \alpha$-androstan3a,17ß-diol. Molec. cell. Endocr. 7, 203-219.

Ritzén, E.M., French, F.S., Weddington, S.C., NAyfeh, S.N. \& Hansson, V. (1974) Steroid binding in polyacrylamide gels. Quantitation at steady state conditions. J. biol. Chem. 249, 6597-6604.

Ritzén, E.M., Hagenäs, L., Purvis, K., Guerrero, R., Johnsonbaugh, R.E., DYm, M., French, F.S. \& Hansson, V. (1977) Androgens and androgen binding protein (ABP) in testicular fluids. In Maldescensus Testis, pp. 79-87. Ed. J. R. Bierich. Urban and Schwarzenberg, Munich.

Tindall, D.J., French, F.S. \& Nayfeh, S.N. (1972) Androgen uptake and binding in rat epididymal nuclei, in vivo. Biochem. Biophys. Res. Commun. 49, 1391-1397.

Received 4 April 1977 